\title{
Fill Out Form
}

National Cancer Institute

\section{Source}

National Cancer Institute. Fill Out Form. NCI Thesaurus. Code C97566.

Enter requested information onto a form. 